\title{
Erratum to: Chapter 1
}

\section{Erratum to: \\ Chapter 1 in: A. Singh, The Process of Social Value \\ Creation, Contributions to Economics, https://doi.org/10.1007/978-81-322-2827-1_1}

\begin{abstract}
After publication of the book, it was brought to the author's attention that the reference "(Varman R, Kappiarath G 2008)" was incorrectly cited in Chapter 1: Introduction. The correct citation is "(Varman R 2008)" and the correct reference is:

"Varman R (2008) The political economy of markets and development: a case study of health care consumption in the state of Kerala, India. Critical Sociol 34(1):81-98".
\end{abstract}

The updated online version for this chapter can be found at https://doi.org/10.1007/978-81-322-2827-1_1 